\title{
Development of Learning Device Using Discovery Learning Model with a Scientific Approach on Sequence and Series Material
}

\author{
Vica Defie Marlis Sinolungan*, John Robby Wenas, Wayan Damai \\ Prodi S2 Pendidikan Matematika PPS Unima \\ Universitas Negeri Manado \\ Tomohon, Indonesia \\ *vsinolungan@gmail.com, johnwenas@unima.ac.id, iwayandamai@unima.ac.id
}

\begin{abstract}
This study aims to develop a learning device using the Discovery Learning model with a scientific approach to sequence and series material and analyze its validity and efficiency. The model that will be implemented in the development of the learning device is a modification of the Thiagarajan model known as Four-D Models (4D Model) namely defining, designing, developing, and dissemination. However, the adopted model is the simplified model, limited to the development stage due to limited time and cost. It was found that the product developed was considered as valid, practical and effective. Learning devices has an average score of 3.56 having valid criteria. The results of practicality of learning devices obtained from the average results of the ability of teachers to manage learning, is 3.46 which is categorized as good. Additionally, the student response gathered by questionnaires shown up to $80 \%$ of positive responses by the students. The effectiveness of learning devices is obtained from the analysis of student activities that are categorized as good and from evaluating the student learning outcomes that show the value of concept mastery above 70 .
\end{abstract}

Keywords—discovery learning, scientific, sequence and series

\section{INTRODUCTION}

Education has a very strategic important role in improving the quality of human resources and efforts to realize the ideals of the Indonesian people to realize the general welfare and intellectual life of the nation.

Education prioritizes active participation between teachers and students based on the talents, interests and potential of students and not one-way activities. Learning must be done in two directions and emphasize active interaction between the teacher and students, students with teaching materials, students with the media, and students with students during the learning activities take place.

The Government established the 2013 Curriculum as a development of the SBC Curriculum. One element of change in the 2013 curriculum is that learning activities are carried out using a scientific approach. Scientific approach is an approach that is centered on students so that students actively construct concepts, laws or principles through the stages of observing, formulating problems, proposing or formulating hypotheses, collecting data with various techniques, analyzing data, drawing conclusions and communicating concepts, law or principle found.

The learning process and outcomes in the 2013 curriculum refer to competencies in the spiritual (K1), social (K2), cognitive (K3) and skills (K4) domains. The scientific learning process includes activities (1) observing; (2) asking questions; (3) gathering information; (4) associate; and (5) communicating. One learning model that is applied to a scientific approach is Discovery Learning. The Discovery Learning model is characterized by learning that occurs when students are not presented with lessons in their final form, but are expected to organize themselves.

As Joolingen [1] argues that "Discovery learning is a type of learning where learners construct their own knowledge by experimenting with a domain, and inferring rules from the results of these experiments" [1]. With the Discovery Learning model it is hoped that students can think more intuitively and formulate their own hypotheses. Discovery Learning is learning that emphasizes direct experience and the importance of understanding the structure or important ideas of a scientific discipline, through the active involvement of students in learning. The teacher in this model acts as a stimulus to students to investigate a problem and leads students to prepare for problem solving.

To achieve the basic competencies of each competency standard in the curriculum, teachers can use a variety of methods and create a learning process that takes place by involving students fully and in accordance with the conditions of students and the character of the material being taught. The use and development of learning tools used by teachers is one important factor in achieving this.

Learning tools that are easily developed by teachers are printed forms, one of which is a learning tool in the form of a 
Learning Implementation Plan (RPP), Student Activity Sheet (LKPD) and Learning Outcomes Evaluation (EHB). From the survey conducted by researchers, there are still teachers who have difficulty in developing scientific learning activities to implement teacher books and student books that already exist. Teachers are still fixated on the content of teacher books and student books and have not yet developed various models in teaching.

In the teacher's book there is a guide to implementing discovery learning in learning activities, but it has not yet been developed in the learning tool. Though learning tools are one of the important aspects of the success of educators in carrying out the teaching and learning process. Learning devices are the guidelines for an educator in carrying out learning activities in class.

The function of the learning tool is as an evaluation material for educators to find out the extent of achievement of the competency standards that have been delivered. In this study learning tools will be developed in the form of RPP, LKPD and EHB which are scientific approaches to the Discovery Learning model which are expected to help teachers and students in carrying out learning activities.

The formulation of the problem is how the development of learning tools and the results of the development of devices using the Discovery Learning model with a scientific approach to the material sequence and series.

\section{RESEARCH METHODS}

A model used to develop learning tools in this study is a modification of the Thiagarajan model known as the Four-D Models (Model 4D), which are defining, designing, developing, and disseminating. The model adopted using a simplified model that is limited to the development stage with consideration of the limited time and cost. The device to be developed is a learning tool which includes a Learning Implementation Plan (RPP), Student Worksheet (LKS) and learning achievement test (EHB) using the Discovery Learning with a scientific approach to the material in the sequence and Series.

\section{RESULTS AND DISCUSSION}

\section{A. Results}

1) Validity of RPP: The lesson plans that have been developed are validated by experts. This validation is done to determine the validity of the lesson plan before the simulation and trial. The RPP is validated by two expert lecturers and two mathematics teachers. Based on the validator's assessment, the average total analysis result of the RPP assessment is 3.56 which means it is very valid.

2) Validation of LKPD: LKPD that has been developed is validated by experts. This validation was conducted to determine the validity of the LKPD prior to the simulation and trial. LKPD was validated by two expert lecturers and two mathematics teachers. Based on the validator's assessment, the average total analysis result of the RPP assessment is 3.64, which means it is very valid.

3) Practicality: Questionnaire responses of students Based on data from the questionnaire responses of students who have been filled out by 38 students after participating in learning activities for material and series using discovery learning models with a scientific approach, it can be said that students' responses to all aspects are above $80 \%$. Then every aspect is responded positively by students.

TABLE I. ANALYSIS OF STUDENT QUESTIONNAIRE RESPONSES

\begin{tabular}{|c|c|c|c|c|}
\hline \multirow[b]{2}{*}{ Description } & \multicolumn{2}{|c|}{ Нарру } & \multicolumn{2}{|c|}{ New } \\
\hline & Frequency & $\begin{array}{c}\text { Percentage } \\
(\%)\end{array}$ & Frequency & $\begin{array}{c}\text { Percentage } \\
(\%)\end{array}$ \\
\hline \multirow{7}{*}{$\begin{array}{l}\text { What do you } \\
\text { think about: } \\
\text { Subject matter } \\
\text { LKDP } \\
\text { Learning } \\
\text { Atmosphere } \\
\text { Ways Teachers } \\
\text { Teach } \\
\end{array}$} & & & & \\
\hline & 35 & $92,11 \%$ & 36 & $94,74 \%$ \\
\hline & 35 & $92,11 \%$ & 36 & $94,74 \%$ \\
\hline & 34 & $89,47 \%$ & 35 & $92,11 \%$ \\
\hline & & & & \\
\hline & 32 & $84,21 \%$ & 34 & $89,47 \%$ \\
\hline & Average & $89,47 \%$ & Average & $92,76 \%$ \\
\hline \multirow{2}{*}{ Description } & \multicolumn{4}{|c|}{ Agree } \\
\hline & \multicolumn{2}{|c|}{ Frequency } & \multicolumn{2}{|c|}{ Percentage $(\%)$} \\
\hline $\begin{array}{l}\text { 1. Your opinion } \\
\text { if the next } \\
\text { subject uses } \\
\text { learning like } \\
\text { this }\end{array}$ & & 6 & \multicolumn{2}{|c|}{$94,74 \%$} \\
\hline \multirow[t]{2}{*}{$\begin{array}{l}\text { 2. Your opinion } \\
\text { if all subjects } \\
\text { use learning } \\
\text { like this }\end{array}$} & & & & \\
\hline & \multicolumn{2}{|c|}{ Average } & \multicolumn{2}{|c|}{$90,79 \%$} \\
\hline \multirow{2}{*}{ Description } & \multicolumn{4}{|c|}{ Ya } \\
\hline & \multicolumn{2}{|c|}{ Frequency } & \multicolumn{2}{|c|}{ Percentage $(\%)$} \\
\hline $\begin{array}{l}\text { 1. Do you } \\
\text { understand } \\
\text { the } \\
\text { language } \\
\text { used in } \\
\text { LKPD? }\end{array}$ & \multicolumn{2}{|c|}{38} & \multicolumn{2}{|c|}{$100 \%$} \\
\hline \multirow[t]{2}{*}{$\begin{array}{l}\text { 2. Are you } \\
\text { interested in } \\
\text { the } \\
\text { appearance } \\
\text { (writing, } \\
\text { letters, } \\
\text { pictures, } \\
\text { colors) on } \\
\text { LKPD? }\end{array}$} & & & & \\
\hline & \multicolumn{2}{|c|}{ Rata-rata } & \multicolumn{2}{|c|}{$97,37 \%$} \\
\hline
\end{tabular}

4) Teacher's Ability to Manage Learning: Based on the criteria of the teacher's ability to manage learning, the average total analysis result of the teacher's ability to manage learning is 3.46 and reaches the "good" category, which is located in intervals of $3 \leq \mathrm{P}<4$. 


\section{5) Effectiveness}

a) Student activity: From the results of observations of the activities of students during learning activities, it can be seen that the activities of students during learning are within the criteria of effectiveness limits, and it can be said that the activities of students during this learning are good.

\section{b) Mastery learning outcomes of students}

TABLE II. COMPLETENESS ANALYSIS OF STUDENT LEARNING OUTCOMES

\begin{tabular}{|l|l|l|l|l|}
\hline $\begin{array}{c}\text { Number } \\
\text { of } \\
\text { Learners }\end{array}$ & $\begin{array}{c}\text { Number } \\
\text { of } \\
\text { students } \\
\text { who have } \\
\text { completed }\end{array}$ & $\begin{array}{c}\text { Percentage of } \\
\text { completeness }\end{array}$ & $\begin{array}{c}\text { Number } \\
\text { of } \\
\text { learners } \\
\text { who do } \\
\text { not } \\
\text { complete }\end{array}$ & $\begin{array}{c}\text { Percentage of } \\
\text { Inaction }\end{array}$ \\
\hline 38 & 38 & $100 \%$ & 0 & $0 \%$ \\
\hline
\end{tabular}

Based on the above table, it can be seen that the percentage of the number of students who reach completeness is included in the very good criteria with a percentage of $100 \%$. This shows that learning tools developed after effective use in learning activities.

c) Analysis of learning outcomes evaluation data: The EHB trial aims to obtain data on the validity of the items, the reliability of the questions, and the sensitivity of the items which will determine whether the evaluation questions developed need to be revised or not. The results of the analysis of the three indicators are as follows.

6) Validity: Based on the product moment correlation formula, the validity of each item is obtained as follows.

TABLE III. RESUlTS OF ANALYSIS OF VALIDITy OF PROBLEM ITEMS

\begin{tabular}{|l|l|l|l|l|l|}
\hline $\begin{array}{c}\text { Questions } \\
\text { number }\end{array}$ & $\boldsymbol{r}_{\text {say }}$ & $\begin{array}{c}\text { Validity } \\
\text { Level }\end{array}$ & $\begin{array}{c}\text { Questions } \\
\text { number }\end{array}$ & $\boldsymbol{r}_{\text {axy }}$ & $\begin{array}{c}\text { Validity } \\
\text { Level }\end{array}$ \\
\hline 1 & 0,617 & Valid & 6 & 0,623 & Valid \\
\hline 2 & 0,614 & Valid & 7 & 0,652 & Valid \\
\hline 3 & 0,735 & Valid & 8 & 0,615 & Valid \\
\hline 4 & 0,624 & Valid & 9 & 0,617 & Valid \\
\hline 5 & 0,614 & Valid & 10 & 0,600 & Valid \\
\hline
\end{tabular}

Based on the table above, the level of validity of each test item is in the "high" category. Then all test items can be said to be valid.

7) Reliability: Based on the calculation results, the reliability coefficient $\alpha=0.823$ was obtained. From the results obtained, the reliability of the Learning Outcomes Evaluation instrument developed is included in the "high" category, and the instrument can be said to be reliable.

8) Sensitivity: The results of the calculation of the item sensitivity values are as follows:

TABLE IV. RESULTS OF THE RESULTS OF SENSITIVITY ANALYSIS OF PROBLEM ITEMS

\begin{tabular}{|l|l|l|l|l|l|}
\hline \multicolumn{1}{|c|}{ Questions number } & \multicolumn{1}{|c|}{$\mathbf{1}$} & \multicolumn{1}{|c|}{$\mathbf{2}$} & \multicolumn{1}{|c|}{$\mathbf{3}$} & \multicolumn{1}{|c|}{$\mathbf{4}$} & \multicolumn{1}{|c|}{$\mathbf{5}$} \\
\hline Sensitivity Index & 0,742 & 0,666 & 0,755 & 0,779 & 0,742 \\
\hline Questions number & 6 & 7 & 8 & 9 & 10 \\
\hline Sensitivity Index & 0,742 & 0,666 & 0,755 & 0,779 & 0,742 \\
\hline
\end{tabular}

Based on the criteria of the test items it is said to be good if the sensitivity of the test items is between 0 and 1 , and an item said to be sensitive to learning if sensitivity is greater or equal to $0.30(\mathrm{~S} \geq 0.30)$. This means that from all items of evaluation of learning outcomes, questions developed are considered sensitive to learning. Thus, from the table all items can be said to be sensitive.

\section{B. Discussion}

Based on the previous description, the learning tool developed is "valid" based on expert validation, "practical" based on the results of the teacher's ability to manage learning that is categorized well and students' responses to positive learning seen from the results of the student questionnaire responses, and "effective" based on activity analysis students are categorized as good and classical learning outcomes are complete.

Thus, mathematics learning tools have been produced using discovery learning models with a scientific approach to row and series material in class XI of SMA Negeri 1 Amurang. The learning tools produced include RPP, LKPD, and EHB

\section{CONCLUSION}

- Mathematics learning tool discovery learning model with a scientific approach to the row and series material is developed using a 4-D development model that is modified so that it becomes 3 stages: defining, designing, and developing producing learning tools that valid for sequence and series material that refers to the discovery learning model and the scientific approach The resulting learning tools (attached in the Appendix) include: lesson plans, student activity sheets, and evaluation of learning outcomes.

- Practical learning tools to teach sequence material and series using discovery learning models with a scientific approach, this is shown from the observations of the teacher's ability to manage learning and students' responses to positive learning.

- Mathematics learning using discovery learning models with a scientific approach to the material row and series in class XI high school can be said to be effective this shows by analyzing the activities of students categorized as good and classical learning outcomes completely.

- Classical learning completeness at EHB shows the percentage of students who complete $100 \%$, students complete individually.

- Student responses are also in positive learning.

\section{REFERENCES}

[1] Joolingen, Wouter Van. 1999. Cognitive Tools for Discovery Learning. International Journal of Artificial Intelligence in Education. 10: 385-397. 